\title{
The Prevalence and Habit-associated Risk Factors of Gastroesophageal Reflux Disease among Fishermen in Indonesia
}

\author{
Ahmad Fariz Malvi Zamzam Zein*, Catur Setiya Sulistiyana*, \\ Tissa Octavira Permatasari**, Uswatun Khasanah***, Tiar Masykuroh \\ Pratamawati ${ }^{* * * *}$, Ismayanti Ismayanti****, Dwi Listiany Corneli ${ }^{* * * *}$, Eni \\ Suhaeni $i^{* * * * *}$ \\ * Department of Internal Medicine, Faculty of Medicine, Universitas Swadaya Gunung Jati, Cirebon \\ ** Department of Medical Education, Faculty of Medicine, Universitas Swadaya Gunung Jati, \\ Cirebon

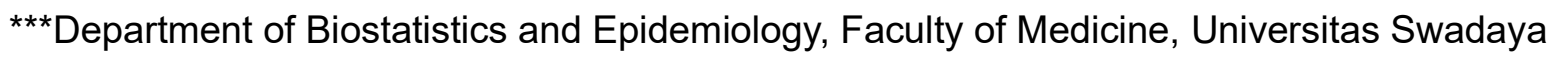 \\ Gunung Jati, Cirebon \\ **** Department of Genetics, Faculty of Medicine, Universitas Swadaya Gunung Jati, Cirebon \\ ${ }^{* * * * *}$ Faculty of Medicine, Universitas Swadaya Gunung Jati, Cirebon \\ $\star * * * * *$ Department of Public Health, Faculty of Medicine, Universitas Swadaya Gunung Jati, Cirebon
}

\section{Corresponding author:}

Ahmad Fariz Malvi Zamzam Zein. Department of Internal Medicine, Faculty of Medicine, Universitas Swadaya Gunung Jati. Jln Taman Pemuda 2 Kompleks Stadion Bima Kesambi Cirebon West Java Indonesia. Phone: +62-231-483928; facsimile: +62-231-488923. Email: fariz_zein_dr@yahoo.com

\section{ABSTRACT}

Background: This study was aimed to investigate the prevalence and habit-associated risk factors of gastroesophageal reflux disease (GERD) among fishermen.

Method: A cross-sectional study was conducted among 168 adult fishermen in Cirebon Regency, West Java, Indonesia. A self-administered questionnaire was given. The questionnaire consisted of demographic characteristics and validated GERD questionnaire (GERDQ) in Indonesian language. A symptom score of at least 8 was considered as GERD. The habits were also reported. Data were analyzed using descriptive statistics and Chi-square test. The study has been approved by the Medical Research Ethic Committee.

Results: The median age of the participants was 39.0 (24-86) years old. They were predominantly (60.7\%) female. The prevalence of GERD was 22.6\%. According to bivariate analysis, there was association between smoking $(P R=1.181 ; 95 \%$ CI: 1.013-1.377; $p$ 0.041), high-salt intake $(P R=2.419 ; 95 \%$ CI: 1.079-5.424; $p$ 0.029), herb consumption ( $P R=3.068 ; 95 \%$ CI: 1.307-7.200; $p 0.008)$, poor hand hygiene ( $P R=3.202 ; 95 \%$ CI: 1.445-7.095; $p$ 0.003), and non-steroidal anti-inflammatory drug (NSAID) consumption (PR $=3.062 ; 95 \%$ CI: 1.446-6.488; $p$ 0.003) with GERD. Tea consumption, coffee consumption, and raw vegetable eating were not associated with GERD.

Conclusion: This population-based study showed that the prevalence of GERD among fishermen in Indonesia is high. Habits associated with GERD in this study were smoking, high-salt intake, herb consumption, poor hand hygiene and NSAID consumption.

Keywords: prevalence, habit, risk factor, gastroesophageal reflux disease, fishermen 


\section{ABSTRAK}

Latar belakang: Penelitian ini bertujuan untuk mengetahui prevalensi gastroesophageal reflux disease (GERD) dan faktor risiko terkait kebiasaan pada nelayan.

Metode: Penelitian potong lintang ini dilaksanakan pada 168 nelayan dewasa di Kabupaten Cirebon, Jawa Barat, Indonesia. Pengumpulan data dari responden menggunakan kuesioner yang meliputi karakteristik demografi, kebiasaan, dan GERD questionnaire (GERDQ) yang tervalidasi dalam bahasa Indonesia. Responden dengan skor gejala sekurang-kurangnya 8 dipertimbangkan sebagai GERD. Analisis data pada penelitian ini menggunakan statistik deskriptif dan uji Chi-square. Penelitian ini telah mendapatkan klirens etik dari Komisi Etik Penelitian Kedokteran.

Hasil: Median usia responden pada penelitian ini 39 (24-86) tahun dan sebagian besar responden (60,7\%) adalah perempuan. Prevalensi GERD didapatkan sebesar 22,6\%. Berdasar analisis bivariat, terdapat hubungan antara merokok $(P R=1,181 ; 95 \% C I: 1,013-1,377 ; p 0,041)$, asupan tinggi garam $(P R=2,419 ; 95 \%$ CI: 1,0795,424; $p=0,029)$, konsumsi jamu ( $P R=3,068 ; 95 \% C I: 1,307-7,200 ; p=0,008)$, kebersihan tangan yang buruk $(P R=3,202 ; 95 \%$ CI: 1,445-7,095; $p$ 0,003), dan konsumsi obat antiinflamasi nonsteroid (PR $=3,062 ; 95 \%$ CI: 1,446-6,488; $p=0,003)$ dengan GERD. Konsumsi teh, kopi, dan lalap tidak berhubungan dengan GERD.

Simpulan: Penelitian berbasis populasi ini menunjukkan bahwa prevalensi GERD pada nelayan di Indonesia tinggi. Pada penelitian ini, beberapa faktor risiko terkait kebiasaan didapatkan berhubungan dengan GERD meliputi merokok, asupan tinggi garam, konsumsi jamu, kebersihan tangan yang buruk, dan konsumsi obat antiinflamasi nonsteroid.

Kata kunci: prevalensi, kebiasaan, faktor risiko, gastroesophageal reflux disease, nelayan

\section{INTRODUCTION}

Gastroesophageal reflux disease (GERD) is, based on the Montreal Consensus, defined as a condition that develops when the reflux of stomach contents into the esophagus causes troublesome symptoms and/or complications. ${ }^{1}$ It is worldwide health problem leading to potential devastating complications, societal consequences, adverse impact on work productivity, and impaired quality of life. ${ }^{2-4}$ Its intriguing diagnostic tools and its complex approach of management contribute the huge burden. It is urged to strengthen the prevention strategy by restricting the risk factors of GERD.

The prevalence of GERD is considerable geographic variation and is increasing worldwide, including Asia-Pacific region..$^{2-4}$ Eusebi et al reported that pooled prevalence of GERD worldwide is $14.8 \%{ }^{3}$ Two population-based studies in Asia-Pacific region reported high prevalence of GERD, those were Taiwan (25\%) and India (18.7\%). ${ }^{4}$ Abdullah et al showed that the prevalence of GERD among urban population in Indonesia is $9.35 \% .5$

Beside geographical difference, certain lifestyle or habit is known as risk factor for GERD as well. Each community has its own specific habit. This study was aimed to investigate the prevalence of GERD and its habit-related risk factors among fishermen in Indonesia.

\section{METHOD}

This population-based, cross-sectional study was conducted in Januari - Maret 2018 in littoral area at the village of Gebang Mekar, Gebang Sub-district, Cirebon Regency, West Java, Indonesia. The participants in this study were randomly selected using stratified random sampling method among healthy individuals aged more than 18 years old. There were no specific exclusion criteria.

This survey used instrument for determining the baseline characteristics of the participants, habits, and validated GERD questionnaire (GERDQ). The baseline characteristics included demographic information regarding sex, age, ethnic, socioeconomic status, level of education, and occupation. Habits in this study encompassed analgetic herb (jamu pegel linu) consumption, tea consumption, coffee consumption, raw vegetable (lalap) eating, high-salt intake, and nonsteroidal anti-inflammatory drug (NSAID) consumption. The status of GERD is determined by symptoms score system known as GERDQ. The positive GERD-related symptoms in the GERDQ included heartburn (burning sensation behind the breastbone), regurgitation (the sensation of stomach contents, either liquid or food, moving upwards to throat or mouth), sleeping difficulty due to heartburn and/or regurgitation, and the additional medication taken for heartburn and/or regurgitation. 
The negative GERD-related symptoms in the GERDQ included epigastric pain and nausea. We used validated GERDQ in Indonesia language in this study as valid and reliable for Indonesia-speaking persons. ${ }^{6}$ Score of 8 or more was the recommended cut-off point to define GERD status.

The sample size was calculated to assess prevalence of GERD. We used a $9.35 \%$ prevalence rate from a previous study in Indonesia, ${ }^{5}$ population size of fishermen in Gebang Sub-district 6825 persons, ${ }^{7}$ confidence level of $95 \%$, and margin of error $5 \%$. The calculated sample size was 128 . We proposed to recruit 168 participants in this study.

Baseline data were presented as mean (SD) for parametric variables, median (range) for nonparametric variables, and frequencies (proportions) for categorical variables. Prevalence ratio (PR) with $95 \%$ confidence intervals were derived using logistic regression models. On bivariate analysis, only variables with $p \leq 0.05$ were considered as significantly associated with GERD. The data were analyzed using IBM SPSS Statistics for Windows, Version 21.0. Armonk, NY: IBM Corp.

This study protocol was approved by the Institutional Review Board, the Medical Research Ethics Committee at the Faculty of Medicine, Universitas Swadaya Gunung Jati, Cirebon, West Java, Indonesia (registration no. 120/EC/FK/XII/2017). Informed consent was confirmed by the IRB.

\section{RESULTS}

A total of 168 respondents were recruited in this study. The baseline characteristics are shown at Table 1. The median age was 39 (24-86) years. They were predominantly female. All of the respondents were Javanese.

\begin{tabular}{ll}
\multicolumn{2}{l}{ Table 1. The baseline characteristics of the subjects } \\
\hline Characteristics & $\mathbf{n}(\%)$ \\
\hline Gender & $78(46.43)$ \\
$\quad$ Male & $90(53.57)$ \\
$\quad$ Female & \\
Age (years) & $85(50.59)$ \\
$\quad<40$ & $57(33.93)$ \\
$40-60$ & $26(15.48)$ \\
$\geq 60$ & \\
Ethnic & $168(100)$ \\
Javanese & $0(0)$ \\
$\quad$ Non-Javanese & \\
Level of education & $122(72.62)$ \\
$\quad$ Below high school & $46(27.38)$ \\
$\quad$ High school or above & \\
Level of income & \\
$\quad<1.500 .000$ IDR & $94(55.95)$ \\
$\geq 1.500 .000$ IDR & $74(44.05)$ \\
\hline
\end{tabular}

Of total respondents, there were $38(22.6 \%)$ respondents with GERDQ score $\geq 8$ (Figure 1). On univariate analysis, NSAID consumption, analgetic herb consumption, high-salt intake, and poor hand hygiene were significantly associated with GERD (Table 2).

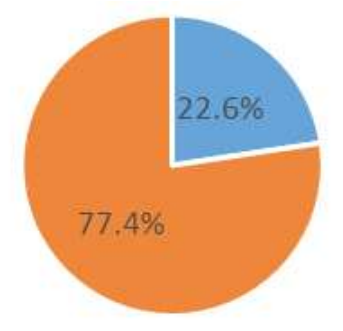

- GERD Non-GERD

Figure 1. Prevalence of GERD in this study

Table 2. The association between habit and GERD

\begin{tabular}{|c|c|c|c|c|}
\hline & $\begin{array}{l}\text { GERD } \\
\mathbf{n}\end{array}$ & $\begin{array}{l}\text { Non-GERD } \\
\mathrm{n}\end{array}$ & $\mathbf{p}$ & $\begin{array}{l}\text { Univariate } \\
\text { PR }(95 \% \mathrm{Cl})\end{array}$ \\
\hline \multicolumn{5}{|l|}{ NSAID } \\
\hline consumption & 19 & 32 & \multirow[t]{3}{*}{0.003} & \multirow{3}{*}{$\begin{array}{l}3.062 \\
(1.446-6.488)\end{array}$} \\
\hline Yes & 19 & 98 & & \\
\hline \multicolumn{3}{|l|}{ No } & & \\
\hline Analgetic herb & & & \multirow{4}{*}{0.008} & \multirow{4}{*}{$\begin{array}{l}3.068 \\
(1.307-7.200)\end{array}$} \\
\hline consumption & 12 & 17 & & \\
\hline Yes & 26 & 113 & & \\
\hline \multicolumn{3}{|l|}{ No } & & \\
\hline Tea consumpt & & & & \\
\hline Yes & 22 & 61 & \multirow[t]{2}{*}{0.234} & \multirow{2}{*}{$\begin{array}{l}1.555 \\
(0.749-3.228)\end{array}$} \\
\hline No & 16 & 69 & & \\
\hline \multicolumn{5}{|l|}{ Coffee } \\
\hline consumption & 8 & 32 & \multirow[t]{3}{*}{0.650} & \multirow{3}{*}{$\begin{array}{l}0.817 \\
(0.340-1.961)\end{array}$} \\
\hline Yes & 30 & 98 & & \\
\hline No & & & & \\
\hline \multicolumn{5}{|l|}{ Raw vegetable } \\
\hline eating & 14 & 43 & \multirow[t]{3}{*}{0.666} & \multirow{3}{*}{$\begin{array}{l}1.180 \\
(0.555-2.508)\end{array}$} \\
\hline Yes & 24 & 87 & & \\
\hline No & & & & \\
\hline \multicolumn{5}{|c|}{ High-salt intake } \\
\hline Yes & 13 & 23 & \multirow[t]{2}{*}{0.029} & \multirow{2}{*}{$\begin{array}{l}2.419 \\
(1.079-5.424)\end{array}$} \\
\hline No & 25 & 107 & & \\
\hline \multicolumn{5}{|c|}{ Poor hand hygiene } \\
\hline Yes & 15 & 22 & \multirow[t]{2}{*}{0.003} & \multirow{2}{*}{$\begin{array}{l}3.202 \\
(1.445-7.095)\end{array}$} \\
\hline No & 23 & 108 & & \\
\hline \multicolumn{5}{|c|}{$\begin{array}{l}\text { GERD: gastroesophageal reflux disease; NSAID: non-steroidal anti- } \\
\text { inflammatory drug }\end{array}$} \\
\hline
\end{tabular}

This is the first study conducted to measure the prevalence of GERD among fishermen in Indonesia. Gebang Sub-district is one of littoral areas in Cirebon Regency, West Java, Indonesia. Of total population 60,899 people, there were 6,825 fishermen in Gebang Sub-district in $2018 .^{7,8}$ We found in this study that the prevalence of symptom-based GERD among fishermen was $22.6 \%$. We also revealed that NSAID consumption, analgetic herb consumption, high-salt 
intake, and poor hand hygiene were associated with GERD.

This study proposes that GERD is high number among fishermen in Indonesia which is higher than the prevalence of GERD among urban population in Indonesia. ${ }^{5}$ Abdullah et al in their study with 278 adult urban population in Depok, Indonesia, found that the prevalence of GERD was $9.35 \%$, using the same validated GERDQ in Indonesia language. ${ }^{5}$ The finding in this study is also higher than the prevalence of GERD among South-East Asian studies. Leonardo HE et al reported that the pooled prevalence of GERD in South-East Asian countries was 7.4 (5.0-10.1)\%. ${ }^{3}$

We reported that NSAID consumption is associated with GERD. It was supported by P Ruszniewski et al in their study with 6,823 French adults reporting that NSAID consumption is a significant risk factor for GERD (OR $=1.64 ; 95 \%$ CI: $1.36-1.98 ; \mathrm{p}<0.01) .{ }^{9}$ Sylvester $\mathrm{CN}$ et al also reported that NSAID use among 3520 Nigerian adults increases the risk of GERD (OR $=1.461 ; 95 \%$ CI: $1.060-2.025 ;$ p 0.021$).{ }^{10}$ Leonardo et al further revealed in their meta-analysis that the pooled prevalence of GERD among NSAID and/or aspirin users was significantly higher than non-users $\left(\mathrm{OR}=1.44,95 \%\right.$ CI: 1.10-1.88). ${ }^{3}$ The NSAIDs affect mucosal damage in the digestive tract through direct mechanism by inhibiting cyclooxygenase (COX) enzymes and indirect mechanism by increasing gastric acid secretion. ${ }^{11}$ Both mechanisms reduce lower esophageal sphincter pressure and promote delayed gastric emptying. ${ }^{11}$ These impacts are responsible for promoting gastroesophageal reflux symptoms.

We demonstrated that analgetic herb consumption is significant risk factors for GERD. Analgetic herb, commonly known as jamu pegel linu, is freely available in the form of powder or liquid at both traditional and modern markets in Indonesia. Andriati et al further reported that almost $50 \%$ of Indonesian people consumed herb in the term of medication or health promotion. ${ }^{12}$ To the best our knowledge, this is the first study evaluating the association between analgetic herb consumption and GERD. There is no clear mechanism of analgetic herb consumption in promoting GERD yet. Some studies detected that analgetic herb may contain mefenamic acid, paracetamol, diclofenac sodium, or ibuprofen. ${ }^{13-16}$ We assumed that analgetic herb had similar mechanism with NSAID in promoting gastroesophageal reflux symptoms due to its contents. Further investigations are needed to clarify this finding.

We reported in this study that high-salt intake was associated with GERD. It is in accordance with study by M Nilsson et al..$^{18}$ They also showed that there was dose-response relationship between high-salt intake and the risk of GERD. ${ }^{18}$ Ping $\mathrm{W}$ et al showed that high-salt intake was associated with reflux esophagitis among 269 subjects in China (adjusted OR $=9.93 ; 95 \%$ CI: $5.33-18.49 ; \mathrm{p}<0.01) .{ }^{19} \mathrm{~T}$ Tanaka et al reported that saline intake inhibited gastric motor activity and delayed solid gastric emptying. ${ }^{20}$ Marissa CA et al showed that high-sodium intake did not increase gastroesophageal reflux in healthy subjects, but it decrease lower esophageal sphincter pressure. ${ }^{21}$ Further studies are needed to investigate this association.

Poor hand hygiene was associated with increased risk of GERD in this study. Hapsari et al reported that poor hand hygiene was associated with the presence of GERD among 90 people in rural area in Jakarta $(\mathrm{OR}=6.93 ; 95 \% \mathrm{CI}: 1.1-43.8) .{ }^{22}$ The mechanism underlying the precipitation and/or aggravation of gastroesophageal reflux by poor hand hygiene is poorly understood. It is assumed that poor hand hygiene can increase risk of gastrointestinal infection that can induce higher gastric acidity and risk for reflux. It is needed to enroll the study investigating this association.

Tea consumption was not associated with GERD in this study. Tao-Yang $\mathrm{W}$ et al in their study among 1,837 persons in Taiwan reported that drinking tea was not associated with reflux symptoms or erosive esophagitis. ${ }^{23}$ Hongying et al in their meta-analysis of 30 studies revealed that there was no significant association between tea consumption and risk of GERD.$^{24}$ However, the role of tea in the development of GERD is still controversial. Chun-Yan et al showed that strong tea was correlated with the increased risk of GERD in Uygur and Han Chinese adult (r 1.124). ${ }^{25} \mathrm{Ai}$ et al demonstrated that the frequent tea consumption was associated with GERD (OR $=2.63$; 95\% CI: 1.24 5.59). ${ }^{26}$ Many aspects may contribute this controversial results, including the type of tea, the frequency of tea consumption, and the mixture of tea (salt, sugar, milk).

This study showed that coffee consumption was not associated with increased risk of GERD. It is supported by some studies reported similar association. ${ }^{23,27} \mathrm{On}$ the contrary, some studies showed that coffee intake induced GERD through direct stimulant to esophagus and further decreased lower esophageal sphincter pressure. ${ }^{28,29}$ John KD reported that coffee intake induced gastrin release and stimulated gastric acid secretion..$^{30}$ A meta-analysis by $\mathrm{J} \mathrm{Kim}$ et al failed to demonstrate significant association between coffee intake and GERD (OR $=1.06$; 95\% CI: 0.94-1.19). ${ }^{31}$

There are several limitations of the present study. 
Firstly, there were no specific details about habit included in this study, such as the type and the quantity of NSAID, and the type, method of processing, and caffeine content of coffee.

\section{CONCLUSION}

The prevalence of GERD among fishermen in Indonesia was high. Habit-associated risk factors are NSAID consumption, analgetic herb consumption, high-salt intake, and poor hand hygiene. Studies with larger numbers of subjects and more detailed about habits are needed to analyze community-specific risk factors.

\section{REFERENCES}

1. Hungin APS, Molloy-Bland M, Scarpignato C. Revisiting Montreal: New insights into symptoms and their causes, and implications for the future of GERD. Am J Gastroenterol 2019;114:414-21.

2. Team R, Hunt R, Canada UK, Armstrong D, Katelaris P, Afihene M, et al. World Gastroenterology Organisation Global Guidelines GERD Global Perspective on Gastroesophageal Reflux Disease 2017;51:467-78.

3. Eusebi LH, Ratnakumaran R, Yuan Y, Solaymani-Dodaran M, Bazzoli F, Ford AC. Global prevalence of, and risk factors for, gastro-oesophageal reflux symptoms: A meta-analysis. Gut 2018;67:430-40.

4. Fock K, Talley NJ, Goh K, Sugano K, Katelaris P, Holtmann G. Asia-Pacific consensus on the management of gastrooesophageal reflux disease: an update focusing on refractroy reflux disease and Barrett's oesophagus. Gut 2016;65:140215.

5. Abdullah M, Makmun D, Syam AF, Fauzi A, Renaldi K, Maulahela $\mathrm{H}$, et al. Prevalence, risk factors and socioepidemiological study of gastroesophageal reflux disease: An Urban population based study in Indonesia. Asian J Epidemiol 2016;9:18-23.

6. Simadibrata M, Rani A, Adi P, Djumhana A, Abdullah M. The gastro-esophageal reflux disease questionnaire using indonesian language: A language validation survey. Med J Indones 2011;20:125-30.

7. Dinas Kelautan dan Perikanan Kabupaten Cirebon. Jumlah Nelayan Perikanan Tangkap Menurut Kecamatan dan Jenis Nelayan di Kabupaten Cirebon, 2018 [serial online]. [cited 2018 December 01] Cirebon; 2018. Available from: https:// cirebonkab.bps.go.id/statictable/2020/01/15/109/jumlahnelayan-perikanan-tangkap-menurut-kecamatan-dan-jenisnelayan-di-kabupaten-cirebon-2018.html

8. BPS of Cirebon District. Penduduk/Population. In: BPS of Cirebon District, editor. Kecamatan Gebang dalam angka (Gebang Sub-district in figures). Cirebon: BPS of Cirebon District; 2018.p.14-28.

9. Ruszniewski P, Soufflet C, Barthélémy P. Nonsteroidal antiinflammatory drug use as a risk factor for gastro-oesophageal reflux disease: an observational study. Aliment Pharmacol Ther 2008;28:1134-9.
10. Nwokediuko SC, Adekanle O, Akere A, Olokoba A, Anyanechi $\mathrm{C}$, Umar SM, et al. Gastroesophageal reflux disease in a typical African population: A symptom-based multicenter study. BMC Gastroenterol 2020;20:1-8.

11. Mungan Z, Şimşek BP. Which drugs are risk factors for the development of gastroesophageal reflux disease? Turkish J Gastroenterol 2017;28:S38-43.

12. Andriyanti, Wahjudi RM. Tingkat penerimaan penggunaan jamu sebagai alternatif penggunaan obat modern pada masyarakat ekonomi rendah-menengah dan atas (Society's acceptance level of herb as alternative to modern medicine for lower, middle, and upper class group. Masyarakat, Kebud dan Polit 2016;29:133-45.

13. Rusmalina S, Khasanah K, Nugroho DK. Deteksi asam mefenamat pada jamu pegel linu yang beredar di wilayah Pekalongan. Pharmacon J Farm Indones 2020;51-60.

14. Indriatmoko D, Rudiana $\mathrm{T}$, Saefullah $\mathrm{A}$. Analisis kandungan parasetamol pada jamu pegal linu yang diperoleh dari kawan industri Kecamatan Kibin Kabupaten Serang (Analysis of paracetamol content in pegal linu herb obtained from the industrial area of Kibin District, Serang Regency). J ITEKIMA 2019;5:33-47.

15. Saputra SA. Identifikasi bahan kimia obat dalam jamu pegel linu seduh dan kemasan yang dijual di Pasar Bandar (Chemical identification herbal medicine packaging and solid herbs pegel pains at Bandar Market). J Wiyata 2015;2:188-92.

16. Rosyada E, Muliasari H, Yuanita E. Analisis kandungan bahan kimia obat natrium diklofenak dalam jamu pegal linu yang dijual di Kota Mataram (Analysis of diclofenac as drug chemical in jamu for rheumatism sold in Mataram city). J Ilm Farm 2019;15:12-9.

17. Kumalasari E, Wahyuni LF, Alfian R. Analisis kualitatif kandungan ibuprofen dalam jamu pegal linu yang beredar di Pasar Baru Permai Banjarmasin. J Pharmascience 2018;5:328.

18. Nilsson M, Johnsen R, Ye W, Hveem K, Lagergren J. Lifestyle related risk factors in the aetiology of gastro-oesophageal reflux. Gut 2004;53:1730-5.

19. Wu P, Zhao XH, Ai ZS, Sun HH, Chen Y, Jiang YX, et al. Dietary intake and risk for reflux esophagitis: a case-control study. Gastroenterol Res Pract 2013;2013.

20. Tanaka T, Mizumoto A, Muramatsu S, Mochiki E, Haga N, Suzuki H, et al. Postprandial normal saline intake delays gastric emptying of solid in conscious dogs: partial involvement of CCK in its mechanism. Dig Dis Sci 1999;44:1516-24.

21. Aanen MC, Bredenoord AJ, Smout AJPM. Effect of dietary sodium chloride on gastro-oesophageal reflux: A randomized controlled trial. Scand J Gastroenterol 2006;41:1141-6.

22. Hapsari FCP, Putri LA, Rahardja C, Utari AP, Syam AF. Prevalence of gastroesophageal reflux disease and its risk factors in rural area. Indones J Gastroenterol Hepatol Dig Endosc 2017;18:9-14.

23. Wei TY, Hsueh PH, Wen SH, Chen CL, Wang CC. The role of tea and coffee in the development of gastroesophageal reflux disease. Tzu Chi Med J 2019;31:169-76.

24. Cao H, Huang X, Zhi X, Han C, Li L, Li Y. Association between tea consumption and gastroesophageal reflux disease A metaanalysis. Medicine (Baltimore) 2019;98(4(e14173)):1-7.

25. Niu CY, Zhou YL, Yan R, Mu N La, Gao BH, Wu FX, et al. Incidence of gastroesophageal reflux disease in Uygur and Han Chinese adults in Urumqi. World J Gastroenterol 2012; 18:7333-40. 
26. Kubo A, Block G, Quesenberry CP, Buffler P, Corley DA. Dietary guideline adherence for gastroesophageal reflux disease. BMC Gastroenterol 2014;14:1-9.

27. Boekema PJ, Samsom M, Smout AJPM. Effect of coffee on gastro-oesophageal reflux in patients with reflux disease and healthy controls. Vol. 11, Eur J Gastroenterol Hepatol 1999.p.1271-6.

28. Price S, Smithson K, Castel D. Food sensitivity in reflux esophagitis. Gastroenterology 1978;75:240-3.

29. Gudjonsson H, McAulife T, Kaye M. The effect of coffee and tea upon lower esophageal sphincteric function. Laenabladid 1995;81:484-8.

30. DiBaise JK. A randomized, double-blind comparison of two different coffee-roasting processes on development of heartburn and dyspepsia in coffee-sensitive individuals. Dig Dis Sci 2003;48:652-6.

31. Kim J, Oh SW, Myung SK, Kwon H, Lee C, Yun JM, et al. Association between coffee intake and gastroesophageal reflux disease: A meta-analysis. Dis Esophagus 2014;27:311-7. 